\title{
Traceability of Halal Control Point in Material, Production, and Serving to Support Halal Certification in Universitas Brawijaya Canteen
}

\author{
Sucipto Sucipto ${ }^{1 *}$, Luki Hidayati ${ }^{2}$, Claudia Gadizza Perdani ${ }^{3}$, Nur Hasanah ${ }^{4}$ \\ ${ }^{1,2,3}$ Department of Agroindustrial Technology, Faculty of Agricultural Technology, Universitas Brawijaya, \\ Malang 65145 Indonesia \\ ${ }^{1,3,4}$ Halal-Qualified Industry Development (Hal-Q ID), Universitas Brawijaya, Malang 65145, Indonesia \\ ${ }^{4}$ Department of Psychology, Faculty of Social Science and Political, Universitas Brawijaya, \\ Malang 65145 Indonesia \\ e-mail: ciptotip@ub.ac.id*1, lukihidayati@gmail.com², cgadizza@ub.ac.id², tn.hasanah6874@ub.ac.id ${ }^{4}$
}

*Correspondent Author

Received: June 02, 2021; Accepted: August 31, 2021

\begin{abstract}
Halal food certification in the university canteen needs to prepare Halal Assurance System (HAS) implementation. Halal Control Point (HCP) traceability in the canteen is very complicated because it has several menus, processes, and materials. This study aims to trace the HCP on materials, processing and serving in Universitas Brawijaya (UB) Canteen, then provide improvement. This research used seven criteria of $H A S$ 23102 for a restaurant to evaluate the menus, ingredients, production, and serving in UB Canteen. HCP traceability was done on 60 menus from 4 food tenants and one beverage tenant. The results showed that grouping the menus and ingredients facilitates HCP identification. The menu consists of six groups: soup, deepfried, stir-fried, strong spices dish, medium soup, and beverages. The materials consist of fresh ingredients, dry ingredients, and liquids. The menus required 113 materials. There are 16 (14\%) materials HCP, including chicken, beef, noodles, and soy sauce. HCP materials do not meet HAS criteria and be replaced with halalcertified material or halal production process (HPP) description from the producer that needs to be checked by a halal auditor. The HCP did not found in the process and serving because the canteen does not produce and service haram (unlawful) products. Still, there is contamination possibility of haram and najis (unclean in Islamic terms) materials. For prevention, the Standard Operational Procedure (SOP) of production, serving the tenant, employee, and visitor need to be applied. The alternatives are supplying chicken meat and beef from a halal-certified slaughterhouse, monitoring and controlling the tenants' kitchen periodically three months, applying the halal standard for storage in tenant's kitchen and canteen facilities, and food serving in canteen. The HCP traceability of the university canteen according to halal standards, including raw materials, additional materials, processes, and serving, including the equipment used.
\end{abstract}

Keywords: canteen, halal certification, halal control point, halal material.

\section{Introduction}

Safe and halal canteens in universities are essential to support quality generation. The existence of safe and halal canteens is still limited, raising health problems. According to Fitria (2015), in December 2015, 12 students from one of the universities in Bogor were infected with Hepatitis A. This was suspected due to less hygienic food from the campus canteen or the food stands around the campus. In another case, according to Kiswara (2016), in March 2016, there were poisoning cases in Malang regency Indonesia, 12 middle school students were poisoned after consuming meatballs in the school canteen. Therefore, safe and halal canteens in educational institutions need to be followed up.

In Indonesia, the management of university canteens is regarded as insufficient in terms of safety and halal. Sucipto et al. (2018) evaluated UB canteen performance based on halal and safety aspects. The consumers of university canteens are mostly the academic community, for example, in Universitas Brawijaya (UB), has reached around 61,000 people. A large amount of academic community become an opportunity to develop halal, safe, and quality food business. Sukoso et al. (2020) said the urgency to support the halal food business in the university canteen.

UB's rector has authorized the policy to implement the halalan thoyibban academic canteens (HTAC). This canteen was inaugurated by the Ministry of Religion of the Republic of Indonesia in 2016. UB has canteens that accommodate 147 tenants or stands. The tenant was managed by a team that has competence in halal and food safety. The library canteen was selected from all the canteens in UB as halal certification pilot projects. The library canteen was established in 2004; it has four food 
tenants and one beverage tenant.

Halal canteens in universities require halal certification from authorized institutions. Khan \& Khan (2019) said halalness refers to the degree of permissible, lawful, or halal by Muslim consumers. Halal canteens certification, initially controlling fast-food safety to obtain proper hygiene certificates from the local public health officials. This condition is related to the policy of the Assessment Institute for Food, Drugs, and Cosmetics - the Indonesian Council of Ulama (LPPOM-MUI), which requires hygienic certificates for restaurants, canteens, and other fast-foods providers before applying for halal certification. Alzeer et al. (2018) state that halal and thoyyib are essential concepts and have become halal certification requirements. This requirement is in line with the halalan thoyibban criteria in Islam.

Along with this requirement, halal-certified products are confirmed thoyyib. Thoyyib covers aspects of food safety and quality. Alzeer et al. (2018) have been connected halal and thoyyib aspects of the food industry.

Food safety controls in the canteen are widely studied. Veiros, Proença, Santos, Kent-Smith, \& Rocha, 2009) researched food safety practices of canteens in Portugal. Osimani et al. (2018) audited the academic university canteen hygienic, and the results of hygiene were influenced by food preparation, hygiene, and personal protective equipment (clothing). Andrea Osimani, Aquilanti, \& Clementi (2015) and Andrea Osimani, Aquilanti, Tavoletti, \& Clementi (2013) examined the system and Hazard Analysis and Critical Control Points (HACCP) of fresh products in the university canteen. Jianu \& Chiş (2012) studied the hygiene knowledge of food handlers of Small and Medium Enterprises (SMEs) in western Romania. Abdelaal et al. (2019), Ellison et al. (2019), and Qian et al. (2021) audited waste in several university canteens.

Research and preparation of canteens and SMEs about processed food are related to document preparation, application of Halal Assurance System (HAS), and submission of halal certification are still limited. Perdani et al. (2018) and Perdani et al. (2017) examined HAS in a hotel, restaurant, and bakery business. Nurmaydha et al. (2018b) studied halal restaurant development strategies. Setiyawan et al. (2017) examined the halal costs in the UB library canteen. Sucipto et al. (2018b) evaluate consumer ratings of UB canteen performance. Therefore, researching the halal certification at the university canteen helps recognize the general obstacles to halal certification preparation and submission.

The vital stage in applying for halal certification is preparing the documents and implementing HAS, one of which is identifying Halal Control Points (HCP). Identifying HCP in the canteen is very complicated because it has various menus, production, and ingredients. Information on raw material origin, production, and serving of the menu should be known so that the HCP and its controls can be appointed. HCP identification requires an alternative of halal-certified materials.

In Indonesia, HCP canteen identification can refer to HAS-23102 (LPPOM MUI, 2015). The HAS-23102 method has 11 criteria. HCP identification consists of written procedures of critical activities, traceability, handling of products that do not meet the criteria, and internal auditing. Zzaman et al. (2013) state the combination of HACCP and halal uses five principles as preliminary stages and seven principles of HACCP. The preliminary stage is the preparation of product descriptions and flows diagrams. The approach to empirical research adopted for this study was the combination of the preliminary steps and HCP identification (HAS-23102). An objective of this study was to assess the $\mathrm{HCP}$ of materials, processes, and serving, then provide alternative improvements to support the halal certification process in the university canteens.

\section{Materials and Methods}

This research was conducted at the library canteen of Universitas Brawijaya (UB) Malang, East Java, Indonesia. Descriptive methods were used to obtain research data related to HCP materials, processes, and menus serving in each tenant. Method refers to HAS 23002 on HAS 23102 Guidelines for Criteria of Halal Assurance System in Restaurants (LPPOM MUI, 2015). The data relating to menus description and HCP materials (raw materials and supplementary materials) were obtained through the ingredients matrix of HAS and interview. The data relating to the production process (production, storage, and utensil cleaning) and menu serving (serving and display process and the cutlery usage) were obtained by interview and observation. We interviewed and observed four food tenants and one beverage tenant gather primary data. Secondary data includes internal and external data of raw material. The data contains a menus description, raw materials origin, production stages, and serving method. Production and serving related to processing and serving equipment. 
The data analysis in this study was carried out by evaluating the menus and materials that have been used by the tenants using two steps, namely the preliminary stages and HCP identification. This stage of study has been used by Nurmaydha et al. (2018b) to determine HCP in Shariah concept restaurants. The stages are as follows. (1) Menu description; (2) Menu grouping; (3) Written procedure for critical activities: Materials purchasing, Materials inspection, Storage and material handling, New materials and new suppliers selection, Production, Washing the production equipment and auxiliary equipment, Formulation or developing a new menu, Display and serving, Visitor rules, and Employee rules; (4) Traceability; (5) Handling of products that do not meet the criteria; (6) Internal audit; (7) Implications to assure the halal material, process, and serving.

\section{Results and Discussion}

\subsection{Overview of University Canteen}

University canteens aim to support educational goals. University canteens should have the proper condition to create a better academic atmosphere that encourages educational purposes. Universitas Brawijaya (UB) has the policy to develop a HTAC starting from 2016. The UB library canteen was used as the pilot project. Initially, this canteen used a rental system (IDR 300,000 per month per tenant) and provided $10 \%$ of sales turnover, but now it is changed by a profit-sharing scheme. The tenants in this canteen were initially managed by the UB Rectorate office, while the UB Canteen Management Team was organized under the UB Non-Academic Business Entities (BUNA). The library canteen has six employees, namely four cleaning services and two cashiers. It operates on Monday-Friday from 08.00 a.m. to 04.00 p.m. and consists of five tenants, i.e., four food tenants and one beverage tenant. The layout of the library canteen is shown in Figure 1.

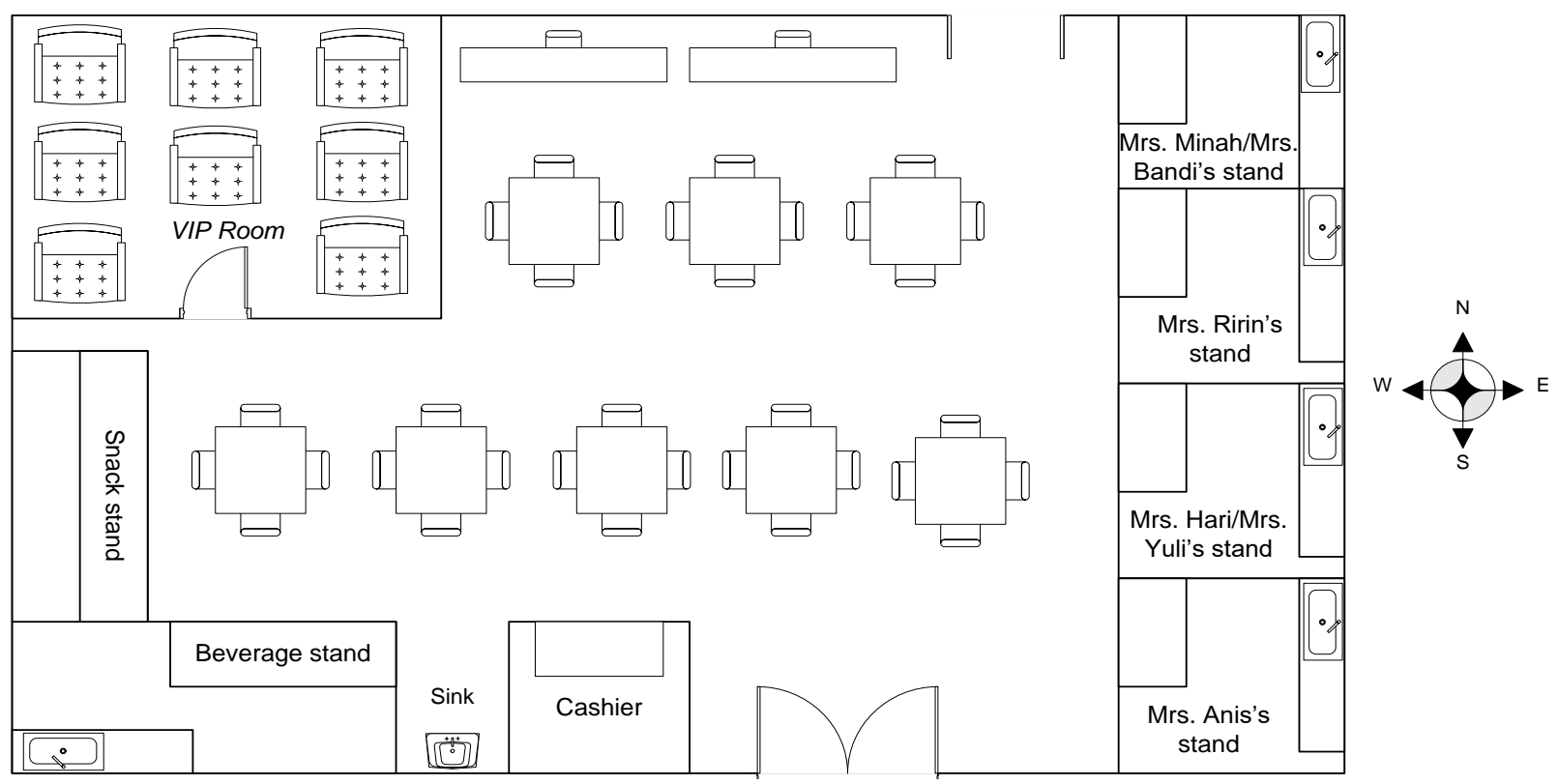

Figure 1 . The layout of the UB library canteen

In addition to the standard room, there is a VIP room which is quite comfortable for small group discussions. Each tenant is responsible for their stand's cleanliness while the cleaning services can clean the space for visitors and wash the canteen cutlery.

\subsection{Menu Description}

The menu consists of local food, drinks, and snacks. The list of the menus in each tenant is in Table 1 . These menus are urgently identified for tracing the ingredients. Menus require to be the group to make it easier for the HCP tracing.

\subsection{Menu Grouping}

The menu in the UB library canteen is divided into seven groups, namely soup, deep-fried, stirfried, strong spices dish, medium-soup, beverages, and snack. The primary menu grouping is shown in Table 2. Menu grouping is based on justification for managing an extensive menu. According to 
Taringan (2014), menus are grouped by consumer demands (menus arranged with prices), namely a la carte menus (the prices were offered per one menu), table d'hôtel menus (the prices were offered per set menu or special deals), and special party menu (menu for special occasions). According to Subroto (2003), there are five types of dishes in the general standard of menu grouping: appetizers, soups, main courses, dessert, and coffee or tea. The menus grouping in the UB library canteen is based on processing techniques. In general standards, menus are grouped into main courses, soups, and drinks. If only grouped into three types of menus, the HCP identification becomes more complicated and less specific. The menu grouping is accorded processing techniques so that HCP easily identification.

Table 1. Tenant's Menu

\begin{tabular}{ll}
\hline \multicolumn{1}{c}{ Tenant } & \multicolumn{1}{c}{ Menu } \\
\hline Broccoli stand (Mrs. & Soto ayam (Indonesian yellow chicken soup), nasi campur (side dishes: fried \\
Anis) & tempe, fried tofu, and various stir-fried vegetables (green bean, cabbage, and \\
& potatoes, and tempeh), Bali (spicy eggs and tofu), ayam kecap (chicken seasoned \\
& with soy sauce), chicken liver satay, rendang ati, ikan tongkol bumbu rujak \\
& (mackerel tuna with rujak seasoning), urap-urap (Javanese salad with seasoned \\
& coconut flakes), sayur bayam (spinach soup), and sayur asem (sour vegetables \\
& soup), and fried rice.
\end{tabular}

Green mustard stand (Mrs. Ririn)

Carrot stand (Mrs. Hari and Mrs. Yuli)

Spinach stand (Mrs. Bandi and Mrs. Minah)

Beverage stand (Chair of UB Women's Association (Dharma Wanita UB)
Nasi campur (side dishes), ceker pedas (spicy chicken feets), ayam bakar (grilled chicken), and sayur lalapan (fresh vegetables, such as: long beans, lettuce, cucumber, and cabbage), tahu campur (tofu poured with beef broth), soto daging (Indonesian yellow beef soup), and bakso (Indonesian meatballs).

Rujak manis (mixed fruit poured with sweet and spicy sauce), nasi pecel (vegetables poured with pecel (peanut sauce), nasi gudeg (side dish: bacem tofu and tempe), rawon (black soup), lontong sayur or lontong cap gomeh (solid steamed rice wrapped in banana leaf) with sayur labu siam (chayote cooked with coconut milk), nasi campur (side dishes: krengsengan (beef stir-fried), rendang daging (beef rendang), and sate telur puyuh (quail eggs satay), nasi uduk (side dishes: the same with the nasi campur).

Nasi campur (side dishes: sambal terong (eggplant cooked in spicy sauce), sambal (chili sauce), mie goreng (fried noodles), oseng tahu (tofu stir-fried), oseng sayuran (vegetables stir-fried), cap cay (chinese vegetables stir-fried), pepes (mackerel tuna with red sauce), omelet, ayam suwir (shredded chicken meat), ayam rica-rica pedas (spicy chicken), fried mendoan (deep fried tempe), perkedel jagung (corn pancakes), and opor ayam (white chicken curry), gadogado (mixed vegetables with peanut sauce) and soto Banjar (Banjar yellow soup)

Fruit juice (melon, watermelon, guava, orange, and star fruit), tape (fermented cassava) juice, hot ginger drink, cappuccino, strawberry float, avocado float, cappuccino float, teh tarik (tarik tea), es kacang ijo (mung beans ice), es dawet (tapioca jelly with coconut milk and palm sugar), cincau (grass jelly with coconut milk and palm sugar) ice, es degan (coconut water and meat), es degan with orange squash (coconut water and meat mixed with orange juice), es teller (shaved ice dessert with toppings like avocado, jackfruit, coconut meat, tapioca jelly, sugar syrup, and coconut milk), and various water drinks.

Table 2. Basic menu grouping

\begin{tabular}{ll}
\hline \multicolumn{1}{c}{ Category } & \multicolumn{1}{c}{ Basic menu grouping } \\
\hline $\begin{array}{l}\text { Meat-soup and non-meat soup } \\
\text { Deep-fried product }\end{array}$ & $\begin{array}{l}\text { Lots of water contained in the menu } \\
\text { Using a lot of cooking oil to deliver the crispy texture and } \\
\text { savory taste }\end{array}$ \\
$\begin{array}{l}\text { Stir-fried product (ex: vegetables stir-fried, } \\
\text { fried noodles, and fried rice) }\end{array}$ & $\begin{array}{l}\text { Using little cooking oil to delivered dried texture } \\
\text { Strong spices dish/ saucy dish }\end{array}$ \\
$\begin{array}{l}\text { Semi-soup } \\
\text { Beverages }\end{array}$ & $\begin{array}{l}\text { Using strong spices and delivered thick sauce } \\
\text { Fewer water contents than the meat/non-meat group } \\
\text { Consisting of any drinks (juices, various drinks, and mineral } \\
\text { waters) }\end{array}$ \\
\hline
\end{tabular}




\subsection{Flow Diagram}

The ingredients used to make the menu were identified from all the menus. It is essential to know the HCP related to the menu and its components. Figure 2 is an example of a bakso (Indonesian meatball) processing flow diagram associated with identifying ingredients, including HCP. Meatball processing consists of 6 stages, namely shaping the meatballs, meatball soup, dried noodles, tofu, somay, and goreng. This process is quite complicated because it involves many materials and processes that need to be identified by the HCP one by one. For example, making meatball requires beef. Its halalness is greatly influenced by the process of slaughter and meat grinding. The process of slaughtering and meat grinding is usually done outside the tenant kitchens. The process can cause halal or haram animal material if it is not under Islamic law. Therefore, it is necessary to use halal-certified beef.

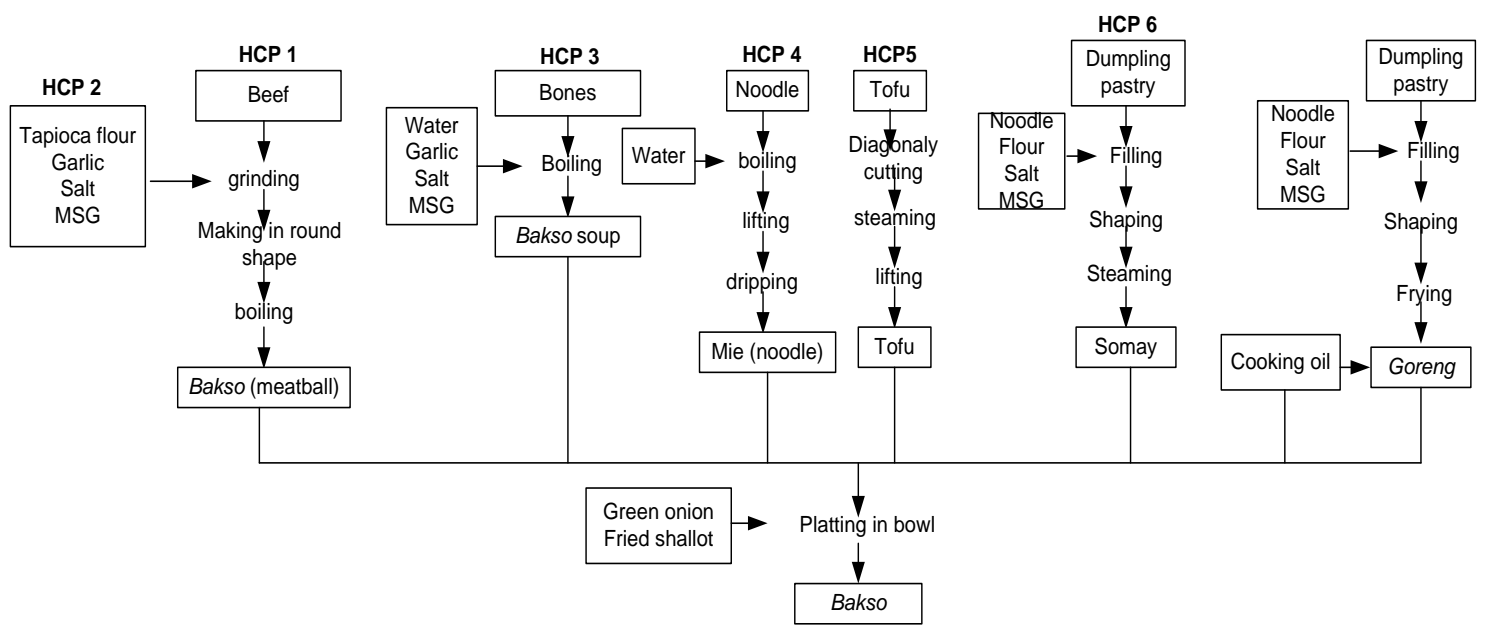

Figure 2. Flow diagram of meatball production and HCP position

\subsection{Written Procedure for Critical Activity}

A standardized set of work procedures to control critical activities was called a written procedure (LPPOM MUI, 2015). The flow diagram of the critical activity procedure is shown in Figure 3.

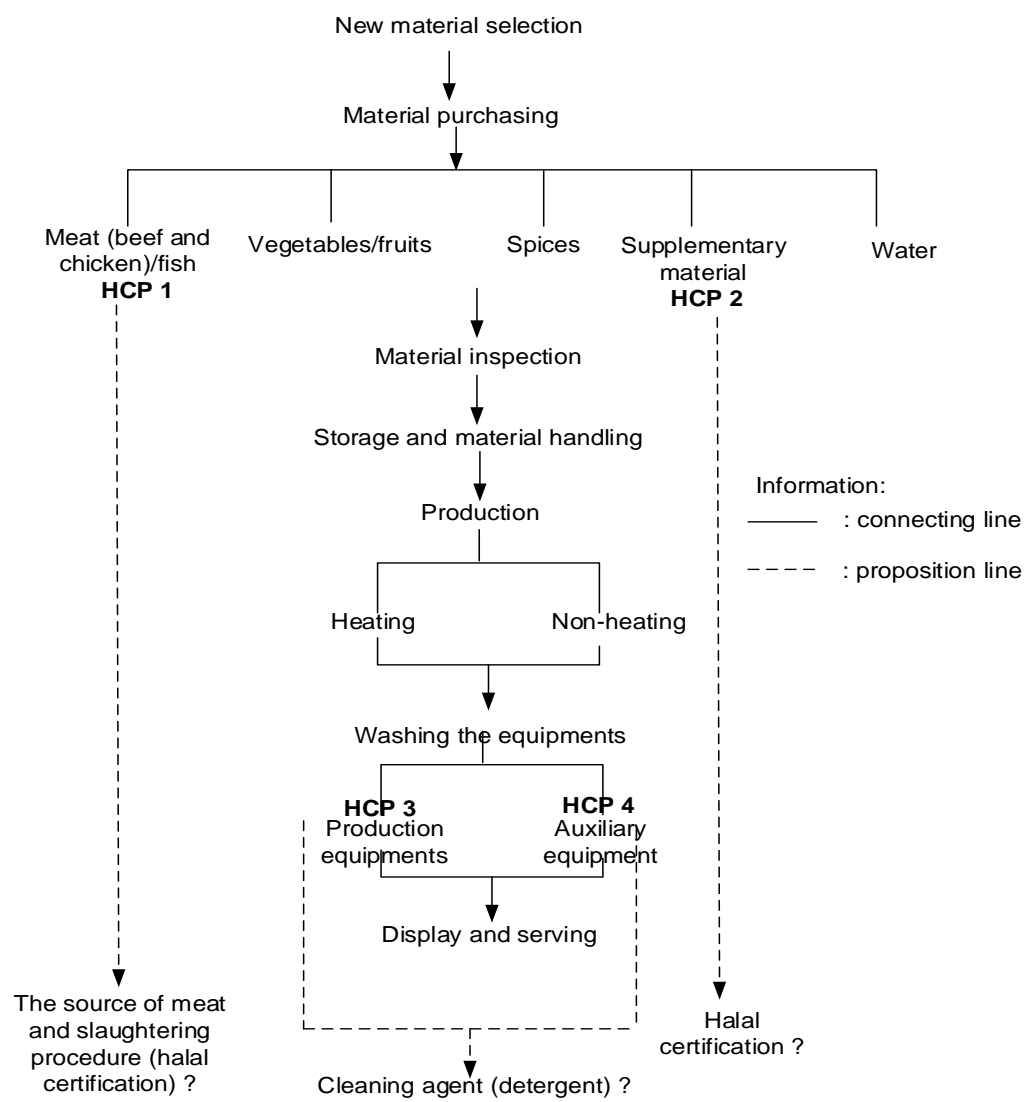

Figure 3. Flow diagram of critical activity written procedure and HCP position

Traceability of Halal Control Point in Material, Production, and Serving to Support Halal Certification in Universitas Brawijaya Canteen 
The flow diagram of a written procedure for critical activity illustrates the critical activity and identification of the HCP possibility in materials and processes. The terms used for this matter are still various, namely halal-critical control points (Halal-CCP), haram control points $(\mathrm{HrCP})$, and halal control points (HCP). These terms were distinguished from the food safety concept, namely critical control points (CCP), so HCP is used in this study. CCP is related to materials and processes in terms of physical, chemical, and biological hazards, while HCP is related to materials and processes in terms of haram (forbidden) and najis (unclean by Islamic terms) material contamination. HCP term has been used to identify HCP fried noodle production (Sucipto, Astuti, \& Harkalih, 2016) and meatball production (Sucipto, Astuti, \& Wurnaningsih, 2016). The description of the HCP identification procedure in the UB library canteen is as follows.

a. Material purchasing was carried out separately for each tenant in traditional markets such as Pasar

Blimbing, Pasar Mergan, and Pasar Tawang Mangu so that the material suppliers were random. This condition makes it difficult to identify HCP materials, so it is necessary to choose a permanent supplier or permanent merk to support HAS implementation.

b. Material inspection; every tenant purchases and checks the coming ingredients individually. The analysis is the freshness of materials and the ingredients and halal logos on the packaging.

c. Storage and material handling; every tenant's kitchen has a storage cabinet. Dried ingredients such as spices are placed in separate containers. Fresh ingredients such as vegetables and meat are placed in the refrigerator. Process dried ingredients (flour, salt, sugar, etc.) are stored in a closed cabinet. The storage of materials for canteen production often mixes with household material. Therefore, all materials stored in the same place need to be guaranteed halal. It is to prevent crosscontamination with non-halal (haram) materials.

d. New materials selection; HCP identification was carried out in all menus except the snack stand menus, and $16 \mathrm{HCP}$ were found. The HCP was shown in Table 3. Because there are many menus, it takes a lot of ingredients. Based on the traced materials, HCP is a critical material (does not have a halal certificate yet). The materials are both from fresh and processed ingredients. The traced HCP ingredients are beef, beef bone, chicken (chicken meat, offal, and chicken feet), tofu, dumpling wrap, kerupuk (crackers), petis (black shrimp paste), terasi (shrimp paste), ground pepper, soy sauce, bread, bread flour, dawet, cincau (grass jelly), ice cream, astor, and tea. These materials need to replace according to the point of material handling that does not meet the criteria.

e. Production activities in each tenant's kitchen are carried out at different times. Tenant only produces halal food (does not provide food such as pork or khamr (alcohol drink). The cooking process is divided into two groups, namely heating and non-heating. The heating process includes: frying, boiling, steaming, roasting, grilling, and stir-frying. Non-heating methods include peeling, cutting and chopping, washing, soaking, blending, and mixing.

The HCP was not affected by heating and non-heating, but the facilities and equipment that are contaminated with haram or najis ingredients affect the halal status of the menu. According to the government regulation on Halal Product Guarantee (LPPOM MUI, 2014b), the halal production procedure should follow the halal production process (HPP). Documentation of the HPP differs depending on the production scale of business and type of business activity, the complexity of the process, personnel competence.

UB library canteen requires the HPP documentation, although its implementation was not easy because the identified menus, ingredients, and processes are very diverse. In contrast to the document in the manufacturing business, it only identified a few products with relatively limited ingredients. HCP identification in the canteen is far more complicated. An example of the production process of bakso in a tenant kitchen is shown in Figure 4 (the detailed process shown in Figure 2). The picture shows the production in a tenant kitchen using simple tools and facilities with household standards. Therefore, HPP standards will be better if applied to food production for domestic use. 




Figure 4. The example of production in tenant's kitchen

f. Washing the production equipment and auxiliary equipment; the cleaning agents should not contain or be contaminated by non-halal (haram or najis) materials. Washing consists of several stages: scraping (separating the food waste), flushing and soaking, washing with cleaning agents, rinsing, and drying. According to Ahmad \& Shariff (2016), the commonly used cleaning agent is water because it is cheap and natural, but the stains, oil, and chemicals may need chemical cleaning agents for better cleanliness. According to Hutami (2014), if cleaning with soil and water is not enough to remove najis, it is necessary to use cleaning agents. Cleaning agents consist of detergents (commercial detergents and clay detergents), acids $\left(\mathrm{HCl}\right.$ and $\left.\mathrm{HNO}_{3}\right)$, and bases $(\mathrm{NaOH})$. The utensils in the UB library canteen were washed with several stages of cleaning and using commercial cleaning agents (detergent).

g. Formulation or developing new menus; the UB library canteen manager states that if tenants want to add new menus, they should submit the proposal to the UB Canteen Management Team. The Management Team assesses new menus. The accepted menu should be reported to the halal certification institution before being produced and sold. This mechanism guarantees the halal menu in the canteen and under the HAS 23102 provisions for restaurants.

h. Display and serving-initially; the serving equipment was provided by each tenant, so it is very diverse. Recently, the serving equipment was arranged uniformly so that it is more aesthetic and cleaner. Serving facilities and types of equipment are devoted only to the menus sold by the UB library canteen. The serving facilities are quite honest because they have been trained and socialized related to the halal and safety of food and halal food serving, such as the canteen menu and serving activity in the UB library canteen shown in Figure 5. Display and serving is a specific procedure for a canteen or restaurant that is not needed in the processed industry.

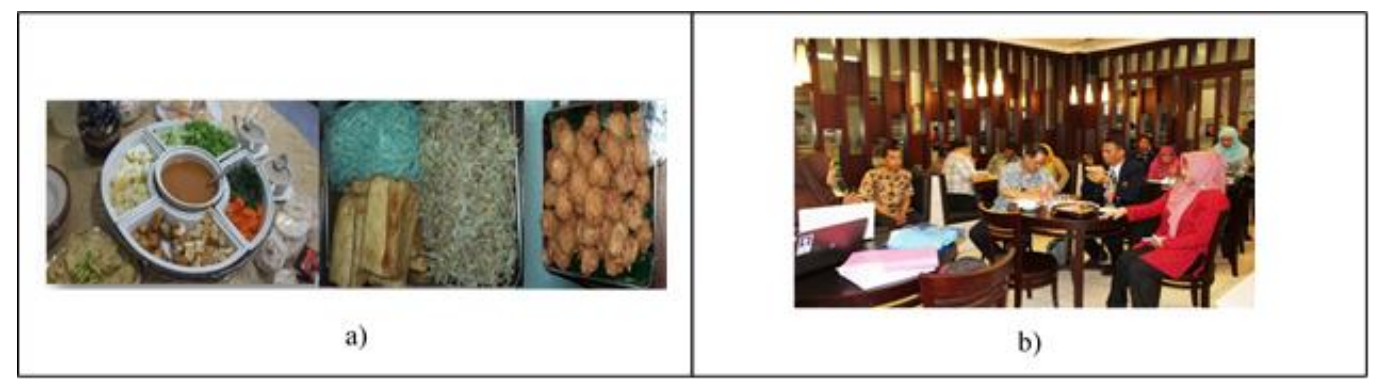

Figure 5. The example of canteen menu (a) and serving activity in UB library canteen (b)

i. Employee and visitor rules; standard rules for visitors have not been applied in the UB library canteen, but the employee rules have been socialized. In general, employees and visitors are not permitted to bring food and drinks that are not halal to the halal canteen, according to HAS 23102 (LPPOM MUI, 2015). This rule ensures that serving menus in the canteen is not contaminated with the menus or products from outside the canteen whose halal status is uncertain through utensils, bowls, spoons, cups, and other serving equipment. Guaranteed halal canteen will be more standardized. 


\subsection{Traceability}

The results of the materials tracing in each tenant are that some materials do not have a brand, making them difficult to identify. Also, some ingredients do not have a halal logo on the packaging. The traced material is about 113 raw materials and supporting materials, including 16 critical materials (14\%), including HCP, so the ingredients did not meet the criteria for halal production (Table 3 ). Materials that do not meet the criteria are given alternative substitute materials revered to the list of certified halal materials. The number of HCP in this study is also consistent with the HCP tracing of hotel restaurants claiming to be sharia hotels (Nurmaydha et al., 2018a). This fact is due to the variety of menus and ingredients for restaurants and canteens.

For example, bread flour is made from wheat flour. If bread flour has no brand, then include HCP (Table 3). Wheat flour processing is often added to vitamins and L-cysteine. Roswiem (2015) states wheat flour from wheat seeds but often enriched with additives such as vitamin A. Vitamin A is usually coated to dissolve quickly and is not easily damaged during storage (LPPOM MUI, 2014a). Coating materials other than halal materials such as gum are also from syubhat (dubious) materials such as gelatin. L-cysteine is an improving agent to improve the properties and quality of the flour. Apriantono (2007) states that L-cysteine can be made from human hair and animal hair. If from human hair, including haram material. L-cysteine from animal hair must be ascertained from halal animals. Therefore, the material used for the production must have a clear brand and have halal certification.

\subsection{Handling of Products that do not Meet the Criteria}

Based on the traceability of the menu and material, some ingredients do not have a brand or halal logo. For example, tofu, dumpling wrap, petis (black shrimp paste), terasi (shrimp paste), white bread, bread flour, cincau (grass jelly), dawet, ice cream, astor, kerupuk (crackers) "Si Unyil," soy sauce "2 ikan bader mas", and ground pepper "Pelangi," and instant tea "999". The selected products are given alternatives for halal materials certified. Beef and chicken meat are substituted halal-certified slaughterhouses. The suggestions for alternative material replacement are shown in Table 3.

Table 3. HCP tracking and alternative ingredients

\begin{tabular}{|c|c|c|}
\hline Material & Brand & Alternative ingredients \\
\hline Tofu & - & Yungfu/inofu/tahu "halim"/sari lezat "Poo" \\
\hline $\begin{array}{l}\text { Dumpling wrap/ } \\
\text { spring roll pastry }\end{array}$ & - & “jay yen” pastry \\
\hline $\begin{array}{l}\text { Petis (black shrimp } \\
\text { paste) }\end{array}$ & - & "Yudhistira" petis (Sidoarjo) \\
\hline Terasi (shrimp paste) & - & "Mamasuka"/ "ABC" terasi \\
\hline White bread & - & "Sari Roti" \\
\hline Bread crumbs & - & "Mamasuka" bread crumbs \\
\hline $\begin{array}{l}\text { Agar-agarl jelly } \\
\text { powder }\end{array}$ & - & Nutrijell Konnyaku Jelly Powder Cincau \\
\hline Dawet (grass jelly) & - & "Sruuut" dawet/cendol flour \\
\hline Ice cream & - & "Diamond" vanilla ice cream \\
\hline Waffer roll & - & "Gery" wafer roll /Arnots Astra chocolate wafer stick \\
\hline $\begin{array}{l}\text { Kerupuk (Indonesian } \\
\text { crackers) }\end{array}$ & Si Unyil & "Finna" crackers \\
\hline Soy sauce & Delmin, 2 Ikan Bader Mas & "Bango"/“ABC"/ "sedap" soy sauce \\
\hline Tea & 999 & $\begin{array}{l}\text { "Tong Tji" premium jasmine tea / "Tong Tji” black tea } \\
\text { / super tea "Tong Tji”" }\end{array}$ \\
\hline Ground pepper & Pelangi & "Ladaku" ground pepper \\
\hline Chicken meat & - & Mua'llim Broiler chicken slaughtering (Batu-East Java) \\
\hline Beef & - & Gadang slaughterhouse (Malang-East Java) \\
\hline
\end{tabular}

Replacement brands of similar materials need to recognize the characteristics of the material being replaced and the substitute material. For example, each soy sauce brand has a different 
sweetness or salinity level. It is necessary to reformulate ingredients to arrange the menu accord to previous taste standards.

There are several considerations in changing ingredients. First, recognize the characteristics and composition of the ingredients replaced and alternative substitutes, especially the taste and aroma. Second, the price of substitute materials is close to the ingredients being replaced so that halal products can remain competitive in the market. Third, substitute materials are available on the market near the place of production and or easily ordered. A commitment of entrepreneurs is needed to reformulate the menu with explicit halal material: the awareness and patience to produce a halal menu according to consumer demands and new halal regulations. The best method of education for small businesses is to be developed.

\subsection{Internal Audit}

Internal audits at the UB library canteen were conducted with direct questions, answers, and tenant's kitchen observation. The canteen was still in the process of obtaining halal certification at internal audit do not all components were following HAS requirements. Overall, the results of the internal audit focused on materials that were not halal-certified and brand.

Monitoring and evaluating the implementation of HAS in businesses or companies require a halal internal audit (LPPOM MUI, 2012). The corrective action from internal audits must be ensured to avoid repeated errors in the future (LPPOM MUI, 2014b). An internal audit was conducted at the UB library canteen after all stages (preparing menu documents, materials, and production processes). The internal audit identifies the processes that are following halal rules and, more importantly, tracing the materials, processes, and serving that do not conform to halal standards. In this study, the internal audit activity was conducted as a simulation, so that it still has weaknesses because the implementation is not comprehensive yet.

\subsection{Implications for Guarantees of Material Halal, Process, and Serving}

The halal standard for restaurants or canteens was debatable (Akhtar et al., 2020). In the UB canteen, there are three halal standards: ingredients, production process, and serving. First, the halal status of the ingredients should be clear. Second, the production process is must be considered to avoid the possibility of cross-contamination. Third, the serving must be regarded as it directly contacts with food or beverage.

The HCP materials were replaced by the new alternatives materials (halal-certified materials or evidence of halal production process (HPP) from the producer if the production has referred to the HPP) and the halal auditors will examine it further. Also, the uncritical material or halal positive list of materials refers to LPPOM MUI No: SK07/Dir/LPPOM MUI/I/13 (LPPOM MUI, 2013). Halal certification becomes the reference for halal menus or ingredients. The elements of canteen menu ingredients are more complex than the processing industry. UB canteen will control the HCP by supplying chicken and beef alternatives for all tenants from halal-certified slaughterhouses. UB Canteen Management Team coordinated this activity. Also, the implementation of material purchasing procedures must be informed and done by tenants, following the Indonesian Ulema Council's standards (MUI) in Figure 6.

The UB Canteen Management Team should monitor the HPP consistently by direct observation in the tenant's kitchen every three months. The direct observation was to evaluate the production so that if there are deviations from the halal production standard, it can be corrected quickly. The application of the Standard Operating Procedure (SOP) of the production process in the tenant's kitchen is essential. Storage and material handling in tenant's kitchens, the ingredients for canteen production were placed in the same place with ingredients for household production. Therefore, it is expected that all stored materials for UB canteen and household production are adjusted to halalan thoyyibban standard so that there is no cross-contamination of haram or najis materials. In this way, the HPP is not only for the needs of UB's canteen matters but also can educate the halalan thoyyibban production system (HTPS) for all family members. 




Figure 6. Material purchasing procedure (LPPOM MUI, 2014)

Ali et al. (2017) and Tieman (2011) provided an integrated view of the concept of halal and thoyyibban relating to product safety, nutrition, and aesthetics. This condition is part of disseminating halal education to the community because there are around 147 tenants in the UB canteen. This halal production education is vital for entrepreneurs as halal certification is mandatory, such as Law No. 33 of 2014 concerning Halal Product Guarantee.

The serving of the menu should use specialized equipment to prevent the cross-contamination of haram or najis materials. Therefore, it is necessary to establish the rules or procedures for the halal serving tenants and employees. Employees and visitors may not bring or consume haram or unclear halal food in the UB canteen. The application of serving SOP for employees and visitors needs to be emphasized.

\section{Conclusion}

Identification of Halal Control Points (HCP) in the UB library canteen is made on materials, production processes, and serving. The results were conducted from all 113 fresh and processed main and additional materials. There were $16 \mathrm{HCP}$ materials (14\%); that need to be replaced with halalcertified materials or halal production certificates from the material producers. Halal guarantee for all tenants' meat ingredients will be efficient with purchasing from halal-certified slaughterhouses by the UB canteen manager. Serving at the UB library canteen is halal guaranteed by Standard Operating Procedure (SOP) for employees and visitors to avoid bringing or consuming food that is not halal in this canteen. The replacement of halal-guaranteed materials and the serving procedure is supporting the halal certification process strongly. The HCP traceability of the university canteen business must be carried out according to halal standards, including raw materials, additional materials, processed, and serving, including the equipment used.

\section{Acknowledgments}

The authors would like to express their gratitude to the Institute for Research and Community Service (LPPM) Universitas Brawijaya, which helped publication develop study centers and study groups in 2020 with contract number 1103.7/UN10.C10/PN/2020. 


\section{References}

Abdelaal, A. H., McKay, G., \& Mackey, H. R. (2019). Food Waste from a University Campus in the Middle East: Drivers, Composition, and Resource Recovery Potential. Waste Management, 98, 14-20. https://doi.org/10.1016/j.wasman.2019.08.007

Ahmad, N., \& Shariff, S. M. (2016). Supply Chain Management: Sertu Cleansing for Halal Logisitics Integrity. Procedia Economics and Finance, 37, 418-425.

Akhtar, N., Jin, S., Alvi, T. H., \& Siddiqi, U. I. (2020). Conflicting Halal Attributes at Halal Restaurants and Consumers' Responses: The Moderating Role of Religiosity. Journal of Hospitality and Tourism Management, 45, 499-510. https://doi.org/10.1016/j.jhtm.2020.10.010

Ali, M. H., Tan, K. H., \& Ismail, M. D. (2017). A Supply Chain Integrity Framework for Halal Food. British Food Journal, 119(1), 20-38.

Alzeer, J., Rieder, U., \& Hadeed, K. A. (2018). Rational and Practical Aspects of Halal and Tayyib in the Context of Food Safety. Trends in Food Science \& Technology, 71, 264-267. https://doi.org/10.1016/j.tifs.2017.10.020

Apriantono, A. (2007). Titik Kritis Kehalalan Produk Bakery dan Kue. Kiblat.

Ellison, B., Savchenko, O., Nikolaus, C. J., \& Duff, B. R. L. (2019). Every Plate Counts: Evaluation of a Food Waste Reduction Campaign in a University Dining Hall. Resources, Conservation and Recycling, 144, 276-284. https://doi.org/10.1016/j.resconrec.2019.01.046

Fitria, L. (2015). Menkes Duga Serangan Hepatitis di IPB karena Kantin Kotor.

Hutami, R. (2014). Deteksi Residu Derivat Babi pada Model Peralatan Industri Pangan Setelah Dicuci dengan Larutan Tanah, Asam, Basa, dan Detergen. IPB University.

Jianu, C., \& Chiş, C. (2012). Study on the Hygiene Knowledge of Food Handlers Working in Small and Medium-Sized Companies in Western Romania. Food Control, 26(1), 151-156.

Khan, G., \& Khan, F. (2019). Ascertaining the "Halalness" of Restaurants - Scale Development and Validation. Journal of Islamic Marketing, 10(2), 426-439. https://doi.org/10.1108/JIMA-042018-0067

Kiswara, B. Y. (2016). Belasan Pelajar SMPN 1 Wonosari Malang Keracunan.

LPPOM MUI. (2012). HAS 23201 Persyaratan Bahan Pangan Halal. Amanah Prima Abadi.

LPPOM MUI. (2013). Daftar Bahan Tidak Kritis (Halal Positive List of Materials).

LPPOM MUI. (2014a). Buku Panduan Olimpiade Halal. LPPOM MUI Bogor.

LPPOM MUI. (2014b). Pedoman Pemenuhan Kriteria Sistem Jaminan Halal di Industri Pengolahan. MUI.

LPPOM MUI. (2015). HAS 23102 Pedoman Pemenuhan Kriteria Sistem Jaminan Halal di Restoran. Amanah Prima Abadi.

Nurmaydha, A., Mustaniroh, S. A., \& Sucipto, S. (2018a). Strategi Pengembangan Restoran Halal Sebagai Penunjang Hotel Syariah (Studi Kasus di Unida Gontor Inn, Universitas Darussalam Gontor Ponorogo). Dinar: Jurnal Ekonomi Dan Keuangan Islam, 5(2), 71-82.

Nurmaydha, A., Mustaniroh, S. A., \& Sucipto, S. (2018b). The Concept Model of Halal Assurance System in the Restaurant (Case Study in UNIDA Inn University of Darussalam Gontor). Jurnal Teknologi Pertanian, 19(3), 141-152. https://doi.org/10.21776/ub.jtp.2018.019.03.1

Osimani, A, Milanović, V., Aquilanti, L., Polverigiani, S., Garofalo, C., \& Clementi, F. (2018). Hygiene Auditing in Mass Catering: A 4-Year Study in a University Canteen. Public Health, $159,17-20$.

Osimani, Andrea, Aquilanti, L., \& Clementi, F. (2015). Evaluation of HACCP System Implementation on the Quality of Mixed Fresh-Cut Salad Prepared in a University Canteen: A Case Study. Journal of Environmental Health, 77(6), 78-85.

Osimani, Andrea, Aquilanti, L., Tavoletti, S., \& Clementi, F. (2013). Evaluation of the HACCP System in a University Canteen: Microbiological Monitoring and Internal Auditing as Verification Tools. International Journal of Environmental Research and Public Health, 10(4), $1572-1585$.

Perdani, C G, Chasanah, N. U., \& Sucipto. (2018). Evaluation of Halal Assurance System (HAS) Implementation on Bakery Products Processing in Small and Medium Enterprises (Case Study in X Bakery Batu, East Java). International Conference on Green Agro-Industry and Bioeconomy, 1-5. https://doi.org/10.1088/1755-1315/131/1/012023

Perdani, Claudia Gadizza, Sucipto, S., \& Angelina, R. (2017). Evaluation of Halal Assurance System in Hotel Restaurant with Syariah Concept to Support Halal Tourism: Case Study at Hotel Fariz Syariah Malang). International Conference Managing Growth for Sustainable Tourism 
Development: Indigeneus, Authentic and Halal Tourism, 285-295.

Qian, L., Li, F., Cao, B., Wang, L., \& Jin, S. (2021). Determinants of Food Waste Generation in Chinese University Canteens: Evidence from 9192 University Students. Resources, Conservation and Recycling, 167, 105410. https://doi.org/https://doi.org/10.1016/j.resconrec.2021.105410

Roswiem, A. P. (2015). Buku Saku Produk Halal: Makanan dan Minuman. Republika.

Setiyawan, D. T., Sucipto, S., \& Yanuardhi, R. (2017). Estimation of the Prerequisite, Certification, and Implementation Cost of Halal Assurance System in Culinary Business (Case Study at UB's Library Canteen). Proceeding The 1st Sustainable Tourism, Halal, and Culture Conference, 296-302.

Subroto, F. Y. D. (2003). Food \& Beverage and Table Setting. Grasindo.

Sucipto, Astuti, R., \& Harkalih, G. B. (2016). Identifikasi Titik Kritis Kehalalan dan Keamanan Produksi Mie Goreng Skala Kecil di Sekitar Kampus Perguruan Tinggi Kota Malang. Seminar Nasional Universitas Darusalam Gontor.

Sucipto, Astuti, R., \& Wurnaningsih, S. (2016). Analisis Implementasi Sistem Jaminan Halal (SJH) di Usaha Waralaba Pangan (Studi Kasus di Waralaba Bakso X). Seminar Nasional dan Lokakarya FKPT-TPI 2016 Universitas Jambi.

Sucipto, S., Rahman, F. S., \& Mustaniroh, S. A. (2018). Analisis Penilaian Konsumen terhadap Kinerja Kantin Perguruan Tinggi. Industria: Jurnal Teknologi dan Manajemen Agroindustri, 7(2), 95-106. https://doi.org/10.21776/ub.industria.2018.007.02.4

Sukoso, Wiryawan, A., Kusnadi, J., \& Sucipto. (2020). Halal Industry Ecosystem (Ekosistem Industri Halal). Departemen Ekonomi dan Keuangan Syariah - Bank Indonesia. Jakarta.

Taringan, N. (2014). Pengertian Restauran \& Jenis-Jenis Restauran (Skripsi). Universitas Sumatra Utara.

Tieman, M. (2011). The Application of Halal in Supply Chain Management: In-depth Interviews. Journal of Islamic Marketing, 2(2), 186-195. https://doi.org/10.1108/17590831111139893

Veiros, M. B., Proença, R. P. C., Santos, M. C. T., Kent-Smith, L., \& Rocha, A. (2009). Food Safety Practices in a Portuguese Canteen. Food Control, 20(10), 936-941.

Zzaman, W., Febrianto, N. A., Zakariya, N. S., Abdullah, W. N. W., \& Yang, T. A. (2013). Embedding Islamic Dietary Requirements into HACCP Approach. Food Control, 34(2), 607612.

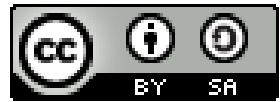

(C) 2021 by Indonesian Journal of Halal Research (IJHAR). Submitted for possible open access publication under the terms and conditions of the Creative Commons Attribution (CC BY SA) license (https://creativecommons.org/licenses/by-sa/4.0/). 